\title{
Insights into the study abroad experience of social education students at Masaryk University, Brno,
} Czech Republic

\author{
Christopher Williams
}

\section{Contact}

Masaryk University

Faculty of Education

Poříčí 623/7

60300 Brno

$\triangle$ Correspondence:

chris.williams@mail.muni.cz

Copyright (C) 2020 by the author and publisher, TBU in Zlín.

This work is licensed under the Creative Commons Attribution International License (CC BY).

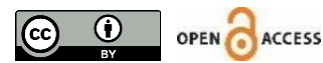

\begin{abstract}
The internationalisation of higher education leads to benefits for students and universities. Part of the internationalisation process is student mobility through study abroad programmes such as Erasmus. This paper reflects on the study abroad process and experience for three Czech social pedagogy students from the faculty of education at Masaryk University in Brno, Czech Republic. The results of this smallscale study, collected through a questionnaire and a follow-up interview, showed that the study participants had similar motivations and experiences despite the different host institutions and study programmes. Furthermore, care needs to be taken when selecting a host university programme and ensuring that there are straightforward activities instructors can make use of to better prepare outgoing students. These findings lead to suggestions for classroom teachers as to how they can, to some degree, 'internationalise' their lessons, and how universities can encourage more students to take part in study abroad programmes, and to questions for future research.
\end{abstract}

Keywords: internationalisation, Erasmus, study abroad, mobility, skill development

\section{Pohled studenta pedagogiky české Masarykovy univerzity v Brně na zkušenost se studiem v zahraničí}

Abstrakt: Internacionalizace vyššího vzdělání je pro student i univerzity př́nosná. Součástí procesu internacionalizace je mobilita studentů v rámci programů pro studium v zahraničí, mezi které patři napríklad Erasmus. Tato práce se věnuje procesu studia v zahraničí a zkušenostem s tímto studiem u tří českých studentů sociální pedagogiky na české Masarykově univerzitě $v$ Brně. Výsledkem této studie malého rozsahu provedené za pomoci dotazníků a následného rozhovoru ukazují, že navzdory různým hostitelským institucím měli účastníci studia podobnou motivaci a zkušenosti. Dále je nezbytné pečlivě vybírat program hostitelské univerzity a dbát na to, aby měli studenti k dispozici jasné instruktážní aktivity, které je lépe připraví na výjezd na hostitelskou univerzitu. Výsledkem těchto zjištění jsou kromě otázek pro další výzkum 
i návrhy pro třídní učitele $\mathrm{k}$ tomu, jak mohou do určité míry „internacionalizovat" svou výuku a jak se mohou univerzity více zapojit do programů studia v zahraničí.

Klíčová slova: internacionalizace, Erasmus, stadium v zahraničí, mobilita, rozvoj dovedností

\section{Introduction}

Internationalisation is defined as "the process of integrating an international, intercultural, or global dimension into the purpose, functions or delivery of postsecondary education" (Knight, 2015, p. 2), to which De Wit, Hunter, Howard, and Egron-Polak (2015, p. 29) add "... in order to enhance the quality of education and research for all students and staff, and to make a meaningful contribution to society." This is an important process for universities - but why? The answers range from the economic (fee-paying international students) to the values of specific faculties and the benefits for students (greater employability options post-graduation).

At the European level, internationalisation is linked to the Bologna Process. The main goal of the Bologna Process was to create and develop a European higher education area with a system of compatible degrees and transferable credits (Kehm, 2010; Teichler, 2012). Student mobility, as part of internationalisation, is enabled by the Erasmus programme, which supports higher education student and staff exchanges (Erasmus+ UK, 2017). Based on findings from a survey involving almost 77,000 former Erasmus students from across Europe, a European Commission (2019) study recently reported that "new evidence shows that Erasmus+ makes students more successful in their personal and professional lives, and helps students find their desired careers and get jobs quicker (para. 4)." The Erasmus+ 2021-2027 (Chircop, 2018) strategy aims to build on this success by increasing its budget to allow more people to take part in the programme, with a focus on assisting and including disadvantaged people.

Most international educators, as well as the Erasmus impact study, would agree that study abroad experience has a significant positive impact on personal growth and the development of academic skills. However, this is of course dependent on the quality of the teaching and curriculum at the host institutions. Roy, Newman, Ellenberger and Pyman (2019, p. 1634) lists studies demonstrating the increased confidence and language ability of those having taken part in a study abroad programme, which includes American undergraduate students studying in France (Allen \& Herron, 2003), Costa Rica (Cubillos, Chieffo \& Fan, 2008), and again in Spain (Hernandez, 2010).

While physical mobility is an important part of internationalisation, the internationalisation process is much more than outgoing students spending the traditional semester abroad. The concept of comprehensive internationalisation (Hudzik, 2011) involves the infusion of international and comparative perspectives throughout higher education. This can be done by changing the means of course delivery (for example, offering a course in a language other than the local one) and the type of content and activities, to allow for more international perspectives and interaction between home and international students (Robson, 2017).

The European Commission also supports international collaboration, alliances, joint degrees, and curriculum and research projects between universities (European Commission, 2020). These collaborations have a positive influence on institutions as well as on home students, who otherwise would not have international experience.

\subsection{Internationalisation and the Czech Republic}

Personal development aside, the importance of Czech students having international experience is a growing necessity given the increasingly multicultural demographics of the Czech Republic. Between 2010 and 2018, the number of foreigners living in the Czech Republic increased year by year - from 424,000 
to 564,000 (CZSO, 2018). This increases the likelihood of those working in education and support services, such as social pedagogues or social workers, of having to work with people who come from a different cultural and linguistic background.

31,342 Czech students took part in Erasmus over the period 2014-2018. Nationally, the number of participants was in steady decline - from 8,228 in 2014 down to 7,272 in 2018 (Erasmust, 2018). Conversely, at Masaryk University in Brno, the numbers increased over the same period - from 535 in the 2013/2014 academic year up to 852 in the 2017/2018 academic year (Masaryk University, 2018). Keen to reverse this trend, and as part of its internationalisation process, Masaryk University in Brno has marked the following areas, amongst others, as key indicators of progress:

- $\quad$ Proportion of students completing a study-abroad stay during their studies.

- Percentage of students who have completed a study-abroad stay, while completing their studies in standard time (Hrabinova \& Coufalova, 2015).

This article reflects on the Erasmus experiences of three undergraduate social pedagogy students from Masaryk University, Brno. In particular, it examines their motivations to take part in the programme, and how the home institution can better prepare and support its students before and during the study abroad period. Finally, it ends with questions for reflection and to guide future research.

\section{Research methodology}

This small-scale research aims to understand why students go on Erasmus, notes any differences in operations between universities, and looks at how the host university can better prepare students for Erasmus.

Knowing the motivation to take part in a study abroad programme means an institution can better understand student perceptions of such programmes. This knowledge can then influence the way study abroad is presented to students, with a view to encouraging more of them to take part. After experiencing a different style of education, students may have been exposed to topics and practices that are perhaps innovative to the home university. These practices may be beneficial in helping students and their teachers develop as social pedagogues. As part of its internationalisation strategy, Masaryk is trying to encourage more students to take part in Erasmus. By learning from the student perspective on what skills were necessary, course teachers can better prepare students for their exchange trip, resulting in a more positive experience.

28 students were contacted over email; all were former students of the researcher from the Department of Social Education at Masaryk University. Of those contacted, three responded. Before any further involvement in the study, they were informed that their names would not be used, and that they were free to discontinue their involvement in the research at any time should they wish to do so. The students were then emailed the Study Abroad Experience questionnaire (Appendix 1). As the students were on Erasmus at this point, they were instructed to complete the questionnaire within a week after finishing their studies. Once complete, the questionnaires were returned by email to the researcher.

\subsection{Participants}

The study participant names have been changed. Tom, Lenka, and Bara are three bachelor-level students of social pedagogy at Masaryk University. Tom and Lenka went on Erasmus in their 3rd semester. Tom went to Spain, and Lenka went to Portugal. Bara went on an Erasmus internship in Spain in her 4th semester, and, at the time of writing, had just started her Erasmus study in Norway for her 5 th semester. The participants' English-language skills ranged from a low $B 2$ to $B 2 / C 1$ on the CEFR scale, more than adequate for them to understand the questions and be able to sufficiently express themselves through speaking and writing. 


\subsection{Data collection}

The participants were emailed the Study Abroad Experience questionnaire to complete and return (see Appendix 1). The questionnaire was original and unique to this study. It consisted of open-ended questions, designed in consultation with a staff member from the Internationalisation Division at Masaryk University. The students received the questionnaire towards the end of their study stay, and returned it one week after completing their studies. This allowed the researcher to study the responses and consider points to explore during the interviews. Then, the participants were invited to discuss their experiences and their questionnaire responses. The researcher facilitated and moderated the discussion between participants and took notes. Before discussion began, the participants were invited to reflect and talk about their Erasmus experience. Once each had had their turn, they compared and contrasted their experiences, and were encouraged to ask each other questions for clarification, the idea being that meaning would be constructed through this reflexive narrative enquiry. The interviews took place in a classroom at the Faculty of Education and lasted approximately one hour. If clarification of a point was required, the researcher would intervene.

Bara was unable to join the group interview - she was in Brno to complete exams and then had to leave to continue her Erasmus stay in Norway, and so was interviewed separately.

\subsection{Limitations}

Though the participants were encouraged to speak candidly and to give 'brutally honest' responses, their answers may have been influenced by the fact that the researcher was their former teacher. In addition, these experiences of a limited number of participants may not have represented common experiences of other Erasmus students.

This study was designed from the perspective of a language teacher at the Department of Social Education at the Faculty of Education. However, I believe the results will be applicable to other instructors at the faculty, and hopefully provide inspiration for non-language-themed classes.

\section{Results}

The results of the questionnaire and subsequent interviews have been divided into thematic areas for analysis: motivations, communication, support, academic participation and institutional differences, developing study abroad skills, and finally, post-graduation.

\subsection{Motivations}

All students who attended the Erasmus programme (internship or study) did so for the adventure. They had either wanted to challenge themselves: I wanted to try a new me, I wanted to experience myself in a totally new environment (Tom), improve their language skills: The only reason was my English ... living and travelling in another country for a while wasn't important to me (Lenka), or had spent time abroad before and wanted to get back out there. Faculty input also played a role - one of Bara's teachers had advised her to apply for the internship.

The choice of host university was not a significant factor for Tom or Lenka; decisions were made because of limited options: It was the only university I could go to in Spain (Tom), or because a friend was going to study there (Lenka). What speaks to Lenka's strength of character is that she decided to continue the Erasmus application process even though her friend dropped out: It will be pretty hard for me and probably the hardest thing in my life, but I can do it. Tom and Lenka chose to study subjects that were similar to those they studied at Masaryk, as they didn't want to have to extend their studies at their home university. Lenka noted that as her host university was a lot smaller than MUNI, her module options were somewhat fewer. 
Though Bara's internship had come about through a recommendation, her motivations to apply for Erasmus study were very different. After going through the break-up of a relationship, Bara realised that she would not feel comfortable remaining in Brno. Also, she had been enjoying her time in Spain and wanted to continue exploring. Bara saw being accepted into a Norwegian university as a form of validation: I didn't expect my application to be successful, but I applied anyway. Norway is a popular destination with a high standard of education; if they accept me then I know I am good enough.

\subsection{Communication}

There was confusion regarding the language of instruction - Tom and Lenka were under the impression that their course would be taught in English, rather than in the local language. This stemmed from a misunderstanding of the host university's website, although they were also assured by the Masaryk team that their courses would indeed be in English. Tom had studied Spanish at school and had gone to the country with the intention of improving his third language, though he expected this would be through social interactions rather than his classes. Still, Tom's abilities were sufficient for him to take part in lessons, aided by support from his teachers. And despite not speaking a word of Portuguese, Lenka was able to complete her assignments in English. Lenka added that her teachers were very supportive - giving her translated copies of lecture notes and offering extra consultation when necessary.

Unfortunately, for Lenka, this was not the only problem - she felt that she had not learnt anything that would ultimately improve her academic skills. Lenka said that the atmosphere at her host university reminded her of being at a high school, and though her classmates and teachers were friendly, they did not seem as professional as those at her home university: This university only gave me (the skill) to be patient when people are trying to explain something to me in Portuguese.

Bara expressed some dissatisfaction with some of her teachers at Masaryk regarding her course completion requirements. She said that replies to her emails took a long time, or never came.

\subsection{Support}

All participants were happy with the support provided by the Masaryk Erasmus team - particularly with the flexibility and response time of certain members of the Faculty of Social Education. Being able to meet to hand over documents at places in town, not just at the faculty during office hours, was seen as very convenient by the students. Students were also happy with the support provided by the host university's Erasmus team, though Lenka noted some difficulties when trying to communicate with the host university's administrative staff.

\subsection{Academic participation and institutional differences}

The participants were happy with the teaching they have received so far at MUNI, and regarding the course content felt prepared for their time abroad. And aside from the teaching-language points made above, they were fairly comfortable interacting with their level of English - apart from the instances in which it was necessary to make themselves understood by somebody with a lower level of English. Lenka had this experience not only with her classmates, but also with some of her teachers. During the focus group, Lenka added that her time in Portugal made her appreciate MUNI even more.

Relating her experience in Norway so far, Bara mentions the number of mandatory classes versus the optional attendance in Spain and at MUNI. In her opinion, making students attend orientation lectures and classes leads to a more well-informed student body, and thus a smoother experience for all taking part. Another difference, she notes, is that she has more time (so far) to study in Norway compared to MUNI. At home, Bara may have to attend several classes a week, as several modules run concurrently, whereas in Norway she has significantly less time in class but more time in the library. 


\subsection{Developing study abroad skills}

In the post-questionnaire interviews, the participants made the following suggestions as to the types of activities that home university instructors could introduce into their classes in order to better prepare outgoing students for study abroad:

- Different types of interaction. Students should have the opportunity to speak with a single partner, in small groups, and with the whole class.

- Post-presentation discussions that develop the ability to handle spontaneous questions from teachers and classmates.

\subsection{Post-graduation}

Tom and Lenka said it was too soon to say if Erasmus had had any impact on their future career plans. On a social level, Tom said that he was planning to visit Spain in the near future to meet up with friends he had made during his time there. Before her internship, Bara had planned to work with people living with hearing impairment. Now, though, she would like to work for Teachers Without Borders, an organisation dedicated to empowering teachers around the world "to gain access to professional development and teaching resources in order to help them become effective" (Teachers Without Borders, 2020).

\section{Discussion}

Although the results come from the responses of only three students, the findings are in line with those of other studies. The motivations of this study's participants to go on Erasmus match those found by Košatka (Ch. Williams, personal communication, January 31, 2020), with wanting to improve language skills and live independently of family being common motivating factors to go on an Erasmus stay. These findings also share some similarities with the research findings of Hahn, Berg, and Korytářová (2017) from other Masaryk students, including: developing independence (p. 7), overcoming fear of the unknown (p. 4), and development of language competencies (p. 11) - this is certainly true in the case of Tom and Bara.

It is interesting to note that academic skills, subject knowledge, or future employment were not given as motivations. These are, perhaps, areas that need promoting in order to attract more students to the Erasmus programme.

Hahn et al. (2017) recorded similar negative experiences: the low level of the internship, or, not having much opportunity to develop (p. 12), local bureaucracy (p. 8), and the lower-than-expected English language level of local staff and/or students (p. 17).

It seems Lenka was not alone with her less-than-positive Portuguese experience. Nada and Araujo (2019) reported issues of international students being accepted into classes taught in Portuguese without their language abilities being verified. Understandably, this leads to dissatisfaction with the education system. Extra care needs to be taken on the part of all involved - the student, host and receiving university - to ensure that there is no confusion regarding the language requirements. Of course, such comments from students at two institutions are not necessarily representative of the general Erasmus experience in Portugal. More positively, Nada and Araujo reported on the supportive nature of the Portuguese instructors and their willingness to adapt lessons where possible to help non-Portuguese-speaking students (2019, p. 1599).

In addition to the students' suggestions, I can add my own suggestions from a language teacher's perspective, based on the results of the study. The skills and activities are those that I expect are already common in many English as a Foreign Language (EFL) or English for Specific Purposes (ESP) classrooms; however, language teachers may need reminding of their useful application in a study abroad context, and they can serve as inspiration for teachers of other subjects: 
- Question forming - this skill has clear multiple applications, including outside the classroom, where students need to be confident in their ability to ask for help or information, and inside the classroom as well. If a student is confident in their ability to ask questions they are more likely to do so, thereby increasing their level of participation.

- $\quad$ Research skills - teaching students how to search for appropriate resources in English could be as simple as encouraging them to use the home university's library in English, along with teaching them how to use and navigate online journal websites or other such e-catalogues.

- $\quad$ Reading skills - particularly the relevance and reliability of academic articles as well as skimming and scanning skills. Teaching or reinforcing the concepts of relevance and reliability, as a part of media literacy, helps students to understand the value of a text for their work. Skimming and scanning refers to the ability to quickly move through a text, looking for and extracting relevant information.

- $\quad$ Listening skills - exposing students to non-native English speakers using English will help students gain familiarity with a range of accents.

General conversation should also not be overlooked; practice in this area will help students better develop their pragmatic skills and relationships with their international classmates and staff at the host university. Košatka (personal communication, January 31,2020 ) makes the point that it is the absence of pragmatics that causes misunderstandings. These skills would go some way towards alleviating the difficulties involved with crossing language barriers. At Masaryk, provided the demands of scheduling and syllabus allow sufficient time, students going on Erasmus should be encouraged to take advantage of the 'general English' language classes available through the university language centre. It is also worth pointing out that there is a dedicated 'study abroad' module available for students at Masaryk's Faculty of Education.

Classroom skills aside, institutions could also consider the issue of study extension. Having to extend studies to take part in Erasmus, or having to study home university subjects while on exchange (as can be the case at Masaryk), either for coursework or exams upon return, reduces the incentive to go on Erasmus.

Finally, given that the motivation of the participants was mostly for personal development through adventure, independence, and improving language abilities, perhaps more students can be encouraged to take part in the programme by raising awareness of the academic and employment benefits of studying abroad.

\subsection{Future research}

The participants who took part in this research completed research tasks soon after returning from the Erasmus programme and before they had started their next semester. Would they have given the same responses if the same information had been collected later, especially regarding their views of academic skills or abilities as social pedagogues developed while abroad? And what about the effects on their postgraduation lives? Bara has already changed her career plans; perhaps the others will too, given enough time to reflect on what they have learnt and achieved. A follow-up study conducted in the participants' academic future would answer these questions.

If the participants are to be employed in the Czech Republic, are Czech employers aware of the usefulness of international experience when hiring and do they consider it valuable? If we consider Johnson and Anderson's statement $(2020,153)$ that the value employers put on studying abroad depends on how the graduates themselves articulate the added value that overseas study has given them, then perhaps a more relevant question is: do students need to be taught how to better 'sell' their experience abroad as a positive for their employers? What is it about the character of those who study social pedagogy? Does the nature of the course attract a certain type of person, one that is more likely to take advantage of study abroad options? And not only that - but also able to break out of the 'Erasmus bubble' that many exchange students find themselves in? Tom said that he had more interaction with his host-nation classmates than with his fellow Erasmus participants, and on her internship, Bara sought more challenging activities after feeling unfulfilled by her assigned position. 


\section{Conclusion}

This article reflected on the Erasmus experiences of three social pedagogy students from a Czech university. The small-scale study aimed to find out the motivations for going on Erasmus, any differences between the home and host institutions, and how the home university can better prepare students for study abroad.

The key motivators were a desire for independence and to improve language skills. Though these are worthy reasons to study abroad, there needs to be a university-wide effort at raising awareness of the benefits of the Erasmus programme, in order to attract students who are not so motivated by adventure and language learning. No significant differences between institutions were noted. The modules studied by the participants were similar in content to those studied at their home university. Regarding preparation, the paper suggested

Simple measures taken before and after study abroad will result in a better experience and wide-ranging benefits for students and institutions. activities commonly found in English-language classrooms and how they could be used within other subjects.

The study participants' experiences show that, most importantly, more investigation is required on the part of the student and Erasmus team at Masaryk to ensure that outgoing students meet the language requirements of the host university. At the same time, host universities must also make the language of instruction clear to potential students. Although there has been mixed opinion regarding the administration of Erasmus at Masaryk, it was pleasing to hear that the social education team were very supportive before and during the students' stay. Generally, however, the social education students' Erasmus experiences are largely in line with those of students from across the university.

In addition, teachers and faculties need to better exploit the experiences of those returning from Erasmus - tapping into new perspectives and skills to further develop teaching and opportunities. Hahn, Berg, and Korytářová (2017, p. 10) reported suggestions that potential Erasmus students should meet with students who are eligible to go on the programme; not only would this help prepare the outgoing students, it would also help dispel any myths surrounding the Erasmus process, and thus encourage more students to take part.

The study ended with more questions needing answers, and suggestions for future research - in particular, regarding the 'Erasmus effect' on students, as they complete their studies, and on their lives postgraduation.

\section{References}

Allen, H. W., \& Herron, C. (2003). A mixed-methodology investigation of the linguistic and affective outcomes of summer study abroad. Foreign Language Annals, 36(3), 370-385. https://doi.org/10.1111/j.1944-9720.2003.tb02120.x

Cubillos, J. H., Chieffo, L., \& Fan, C. (2008). The Impact of short-term study abroad programs on L2 listening comprehension skills. Foreign Language Annals, 41(1), 157-186. https://doi.org/10.1111/j.19449720.2008.tb03284.x

CZSO. (2018). Foreigners: Number of foreigners. Czech Office of Statistics. Retrieved from https://www.czso.cz/csu/cizinci/1-ciz_pocet_cizincu

De Wit, H., Hunter, F., Howard, L., \& Egron-Polak, E. (2015). Internationalisation of higher education. Brussels: Policy department, directorate general for internal policies, european parliament. Retrieved

from https://www.europarl.europa.eu/RegData/etudes/STUD/2015/540370/IPOL_STU\%282015\%2954 0370_EN.pdf 
Williams / Insights into the study abroad experience of social education students ...

Erasmust. (2017). Learning together: An introduction to Erasmust for the UK. Retrived from https://issuu.com/futurekulture/docs/erasmus_learning_together_brochure

Erasmus+. (2018). Number of outgoing students by target countries in 2014/2015 - 2017/2018. Retrieved from https://www.naerasmusplus.cz/cz/mobilita-osob-vysokoskolske-vzdelavani/statistiky/

European Commission. (2019). Erasmust: a turning point in the lives of 5 million European students. Retrieved from https://ec.europa.eu/commission/news/erasmus-turning-point-lives-5-millioneuropean-students-2019-may-20-0_en

European Commission. (2020). Erasmust Programme Guide. Retrieved from https://ec.europa.eu/programmes/erasmus-plus/resources/documents/erasmus-programmeguide-2020_en

Hahn, M., Berg, K., \& Korytářová, A. (2017). Analýza potřeb studentů vyjiždějících na zahraniční pobyty přes CZS. Brno: Masarykova univerzita.

Hernandez, T. A. (2010). Promoting speaking proficiency through motivation and interaction: The studyabroad and classroom learning contexts. Foreign Language Annals, 43(4), 650-670. https://doi.org/10.1111/j.1944-9720.2010.01107.x

Hrabinova, S., \& Coufalova, S. (2015). Dlouhodobý záměr Masarykovy univerzity na léta 2016-2020. Brno: Masarykova univerzita. Retrieved from https://is.muni.cz/do/rect/strategie/ver/Dlouhodoby_zamer_MU_2016_2020.pdf

Hudzik, J. (2011). Comprehensive Internationalization - from concept to action. Washington, D.C: NAFSA: Association of International Educators.

Chircop, D. (2018). Erasmus 2021-2027. The Union programme for education, training, youth and sport. Brussels: European Parliamentary Research Service. Retrieved from https://www.europarl.europa.eu/RegData/etudes/BRIE/2018/628313/EPRS_BRI(2018)628313_EN .pdf

Johnson, M., \& Anderson, C. (2020). The impact of education abroad on competency development. In R. Coelen \& C. Gribble (Eds.), Internationalization and Employability in Higher Education (pp. 49-58). Oxon: Routledge.

Kehm, B. M. (2010). Quality in european higher education: The influence of the Bologna process, change. The Magazine of Higher Learning, 42(3), 40-46.

Knight, J. (2015). Updating the definition of internationalization. International Higher Education, (33), 2 3. https://doi.org/10.6017/ihe.2003.33.7391

Masaryk University. (2018). Annual aktivity report 2018. Retrieved from https://www.muni.cz/media/3169387/mu_vzoc_2018-en.pdf

Nada, C. I., \& Araujo, H. C. (2019). Internationalisation of higher education: evidence from Portugal. Studies in Higher Education, 44(9), 1591-1604. https://doi.org/10.1080/03075079.2018.1458219

Robson, S. (2017). Internationalization at home: internationalizing the university experience of staff and students. Educação, 40(3), 368-374.

Roy, A., Newman, A., Ellenberger, T., \& Pyman, A. (2019). Outcomes of international student mobility programs: a systematic review and agenda for future research. Studies in Higher Education, 44(9), 1630-1634. https://doi.org/10.1080/03075079.2018.1458222

Teachers Without Borders. (2020, January 25). Frequently asked questions. Retrieved from https://teacherswithoutborders.org/faqs/

Teichler, U. (2012). International student mobility in Europe in the context of the Bologna process. Journal of International Education and Leadership, 7(1), 34-49. https://doi.org/10.2304/rcie.2012.7.1.34 


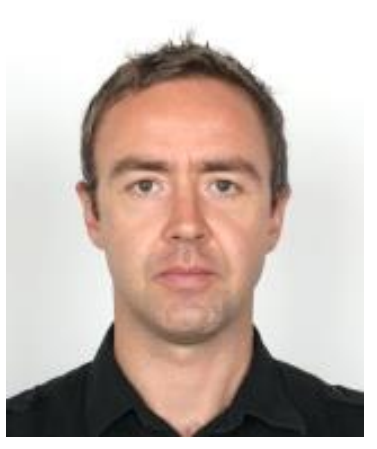

Chris Williams is a language teacher and doctoral candidate at the Faculty of Education, Masaryk University. His area of research is second language acquisition and he also has an interest in the internationalization of higher education. 


\section{Appendix 1}

\section{Study Abroad Experience questionnaire}

1. Why did you go on Erasmus?

2. Why did you choose that university?

3. Think about how you studied at that university:

- What courses/modules/subjects did you take?

- Were there options there that you didn't have at Masaryk?

- Was there much homework? What did you have to do?

- What did your teachers expect from you?

- What did you have to do in class - group projects, presentations, written essays, written reports, etc.

- Was there a 'final assessment'? If yes, what was it? - grammar, vocabulary, essay, listening, reading, etc.

5. In terms of general academic skills, what did you learn? Or, what academic skills did you improve? (academic writing, research, etc.). More specifically, how did your course help you as a social pedagogy student?

6. How was studying social education the same as at Masaryk? How was it different? Did you dislike/like the differences? Why?

7. Think about your English-language skills. How did you cope with:

- Reading/writing/speaking/listening

- Class discussions

- Working in groups

- General conversation/interaction with your teachers and classmates

8. Think about your English lessons at Masaryk:

- Did they prepare you for studying abroad?

- What should future students do more/less of in their Masaryk English lessons to prepare for study abroad? 